\title{
RESEARCH
}

\section{Positional Candidate Genes for Congenital Chloride Diarrhea Suggested by High-resolution Physical Mapping in Chromosome Region 7q31}

\author{
Pia Höglund, ${ }^{1,6}$ Siru Haila, ${ }^{1}$ Stephen W. Scherer, ${ }^{2}$ Lap-Chee Tsui, ${ }^{2}$ \\ Eric D. Green, ${ }^{3}$ Jean Weissenbach, ${ }^{4}$ Christer Holmberg, ${ }^{5}$ \\ Albert de la Chapelle, ${ }^{1}$ and Juha Kere ${ }^{1}$
}

\begin{abstract}
${ }^{1}$ Department of Medical Genetics, 00014 University of Helsinki, Finland; ${ }^{2}$ Department of Molecular and Medical Genetics, University of Toronto, Ontario, Canada and Department of Genetics, Hospital for Sick Children, Toronto, Ontario M5G 1X8, Canada; ${ }^{3}$ National Center for Human Genome Research, Bethesda, Maryland 20892 USA; ${ }^{4}$ Centre National de la Recherche Scientifique (CNRS) URA 1922, Généthon, 91000 Evry, France; ${ }^{5}$ Children's Hospital, University of Helsinki, 00290 Helsinki, Finland
\end{abstract}

Congenital chloride diarrhea affects intestinal transportation of electrolytes, resulting in potentially fatal diarrhea. Linkage disequilibrium analyses have suggested the congenital chloride diarrhea gene (CLD) to lie within $0.37 \mathrm{cM}$ from D7S496 in human chromosome 7q31. To clone the CLD gene, we have constructed and refined a physical map based on a 2.7-Mb YAC contig around D7S496 and identified two candidate genes. The physical positions of 4 known genes (DRA, PRKAR2B, LAMBI, DLD), 7 polymorphic repeat markers, and $13 \mathrm{CpG}$ islands were established. DRA (down-regulated in adenoma) is expressed in the gut and encodes a protein with sequence homology to anion transporters, whereas PRKAR2B encodes a regulatory subunit for protein kinase A. Both genes map within $450 \mathrm{~kb}$ from D7S496, making them functionally and positionally relevant candidates for CLD.

Congenital chloride diarrhea [Mendelian Inheritance in Man (MIM) no. 214700; McKusick 1994] is an autosomal recessive disorder of intestinal electrolyte transportation, manifested as a lifetime profuse watery diarrhea with a high chloride content (Norio et al. 1971). The pathogenesis of the disease is unknown, but the defect appears to impair chloride and bicarbonate trafficking in the distal ileum and colon (Turnberg 1971; Holmberg et al. 1975). The diarrhea begins before birth, causing polyhydramnios and often premature birth. Other features include abdominal distention, dehydration, and metabolic alkalosis resulting in death in early infancy if untreated. The treatment includes daily oral replacement of fluid and electrolyte losses. Appropriately treated children grow, develop, and live normally (Holmberg et al. 1977). In Finland, the disease has a relatively high incidence; elsewhere only

${ }^{6}$ Corresponding author.

E-MAlL pia.hoglund@helsinki.fi; FAX 358-0-434 6677. $\sim 100$ cases have been reported since 1945 when the disease was first described (Darrow 1945; Gamble et al. 1945).

The congenital chloride diarrhea gene (CLD) was previously mapped to chromosome 7 , close to the cystic fibrosis transmembrane conductance regulator gene (CFTR) (Kere et al. 1993). The high prevalence of CLD in the Finnish population provided an opportunity to refine the genetic localization of CLD by the study of linkage disequilibrium. A combination of haplotype analysis and a quantitative approach ("LuriaDelbrück" analysis; Hästbacka et al. 1992) allowed its fine mapping to $0.37 \mathrm{cM}$ telomeric of D7S496 (Höglund et al. 1995). This genetic distance should be well within the range of physical mapping methods. Thus, we studied overlapping yeast artificial chromosomes (YACs; Burke et al. 1987) from two collections enriched for human chromosome 7 (Scherer et al. 1992; Green et al. 1995) and the Centre d'Etudes du Polymorphisme Humain (CEPH) megaclone collection 
PHYSICAL MAPPING IN THE CLD GENE REGION

(Cohen et al. 1993). Long-range restriction mapping was used to confirm, refine, and merge a series of distinct YAC contigs of this region and to identify $\mathrm{CpG}$ islands as indicators for genes. The previously cloned genes down-regulated in adenoma (DRA) (Schweinfest et al. 1993), PRKAR2B (Solberg et al. 1992), human laminin B1 (LAMB1) (Pikkarainen et al. 1987), dihydrolipoamide dehydrogenase gene (DLD) (Scherer et al. 1991), 13 CpG islands, and 7 polymorphic markers (Weissenbach et al. 1992; Gyapay et al. 1994) were placed on the refined map. As a result, these studies identified two positional candidate genes for CLD and suggest the presence of several uncharacterized genes in and around the candidate region.

\section{RESULTS}

\section{Identification of Overlapping YACs}

To cover the CLD candidate region, 51 YAC clones were identified by systematic sequencetagged site (STS) content screening from two chromosome 7-enriched collections (Scherer et al. 1992; Green et al. 1995) and the CEPH megaclone library (Cohen et al. 1993). All screening results were confirmed by PCR assays on DNA extracted from colony-purified clones. STS content mapping (Green and Olson 1990) idenified 14 overlapping segments at D7S496, 8 at D7S501, and 5 at D7S692 (Fig. 1). To close the remaining gap between seed contigs, YAC insert ends were isolated by a ligation-mediated PCR strategy (Kere et al. 1992) and used as probes.

\section{Rare-cutter Restriction Mapping and Contig Refinement}

Altogether 46 YACs were mapped with rare-cutter restriction enzymes. An example of results for two YACs is shown in Figure 2. Restriction maps of tentatively overlapping YACs (see Fig. 1) were compared and used to refine the alignment and orientation of individual YACs. Altogether 13 potential $\mathrm{CpG}$ islands were identified based on our definition that a CpG island contains a restriction site for at least two of the four rare-cutter restriction enzymes used.

D7S501 was connected to AFMa126zc1 and D7S496 by STS content mapping of two large clones from the CEPH collection. The respective physical distance was determined by restriction mapping of the clone $884 \mathrm{f} 9$ and confirmed by restriction mapping of clones $794 \mathrm{c} 5$ and $764 \mathrm{~b} 10$

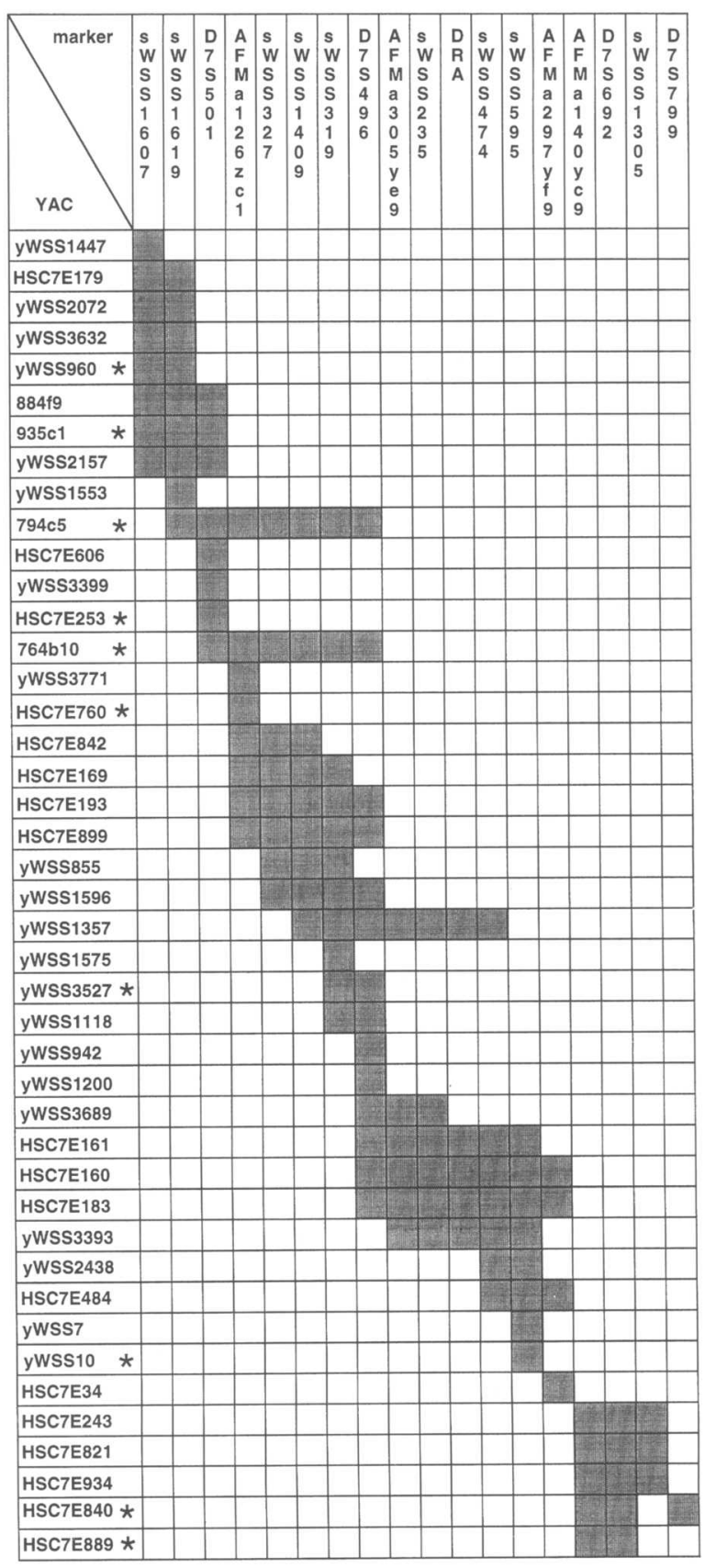

Figure 1 Anonymous STS and polymorphic marker content of YACs. The shaded boxes denote the extent of each YAC. The YACs marked with an asterisk were discarded from the final physical map (see text). The centromere is to the left.

using the enzyme NotI. On the basis of the sizes of the YACs (both $1000 \mathrm{~kb}$ ), and the sizes of respective NotI fragments, the distance between D7S501 and D7S496 was approximated to be $700 \mathrm{~kb}$.

The final distance map comprises 36 YACs 
HÖGLUND ET AL.

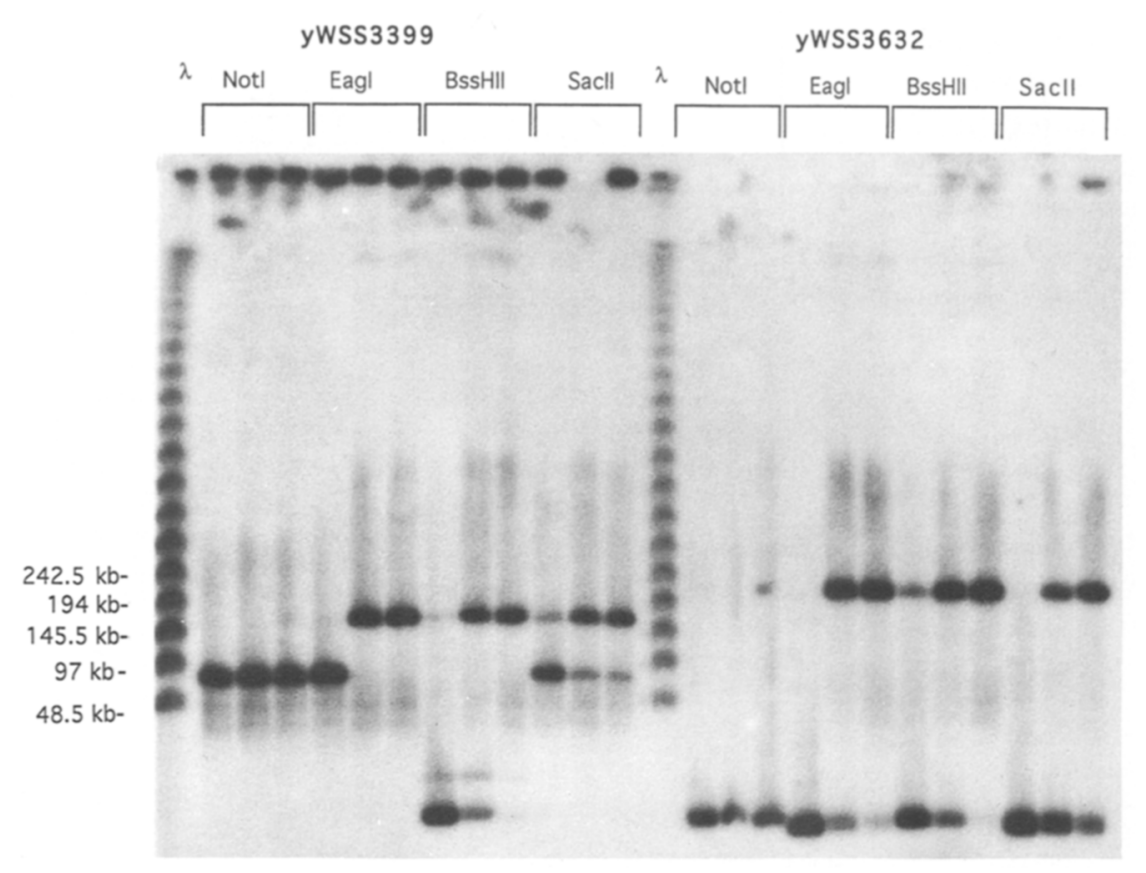

Figure 2 Restriction mapping of YACs yWSS3399 and yWSS3632 using the pBR322-derived left-arm probe. Each enzyme was used at three different concentrations to obtain serial partial digestions. Bacteriophage $\lambda$ concatamer was used as a DNA size marker.

and covers $2.7 \mathrm{Mb}$ of DNA. A summary map of the contig is shown in Figure 3. Three clones were discarded because they contained more than one YAC, five because their restriction maps were inconsistent, one because its location remained ambiguous, and one because of an internal deletion. Four small clones were not considered because of dense coverage around their locations.

\section{Localization of Genes and Markers}

The physical order of the STSs and polymorphic markers in the Généthon (Weissenbach et al. 1992; Gyapay et al. 1994) and Cooperative Human Linkage Center (CHLC) (Murray et al.
1994) linkage maps was determined by PCR assays of overlapping YAC clones. The centromere-telomere orientation of the map was based on linkage markers. Table 1 summarizes data for all markers included in the map. Refined mapping of DRA, PRKAR2B, LAMB1, and DLD and markers D7S 155 and D7S200 (Rommens et al. 1988) was done by hybridizing specific probes to TaqI blots of YACs. The Stanford radiation hybrid panel G3 (Cox 1995) was used to order an additional four markers within and outside the YAC map. The initial screening was performed using PCR markers AFMa288yg1, AFMa126zc1, AFMa297yf9, and D7S799. Positive hybrids were studied with additional markers to define the breakpoints and order adjacent markers. The results are presented in Figure 4 . The following order of DNA markers could be determined: 7 cen-(AFMb320ve 1-AFMa 226 ye 1 )AFMa 052 ya 5-AFMa 288 yg 1-sWSS $1607_{\text {- }}$ sWSS1619-D7S501-PRKAR2B-AFMa126zc1sWSS327.-sWSS1409-sWSS319-D 7S 496(AFMa305ye9-sWSS235)-DRA-sWSS4 74sWSS595-(DLD-LAMB1)-AFMa297yf9-D7S155D7S200-AFMa140yc9-(D7S692-sWSS1305)D7S799-D7S523-qter. Physical distances between the markers are shown in Figure 3.

The LAMB1 gene is known to have a CpG island (Vuolteenaho et al. 1990) that contains restriction sites for all enzymes used (NotI, EagI, $B s s H I I$, SacII). The gene was mapped by hybrid-

Figure 3 Structure of the YAC contig refined by rare-cutter restriction mapping. Individual YACs are indicated by horizontal lines, drawn to the kilobase scale shown at the bottom. A dot for Cen 4 denotes the left end of each YAC. The localization of anonymous STSs, polymorphic microsatellites, hybridization probes, and isolated YAC ends are represented by vertical lines. Brackets are used to indicate ambiguity of order. Genes are shown with shaded boxes below the restriction map. Isolated YAC ends are marked with solid boxes in the respective YACs. The restriction maps of each YAC were drawn independently. The experimental variation is thus reflected in that not all sites in YACs are exactly aligned; the consensus map shown in bold below approximates the consensus positions of rare-cutter sites. The centromere is to the left. (N) Nott; (E) Eagl; (B) BssHll; (S) Sacll. 
PHYSICAL MAPPING IN THE CLD GENE REGION

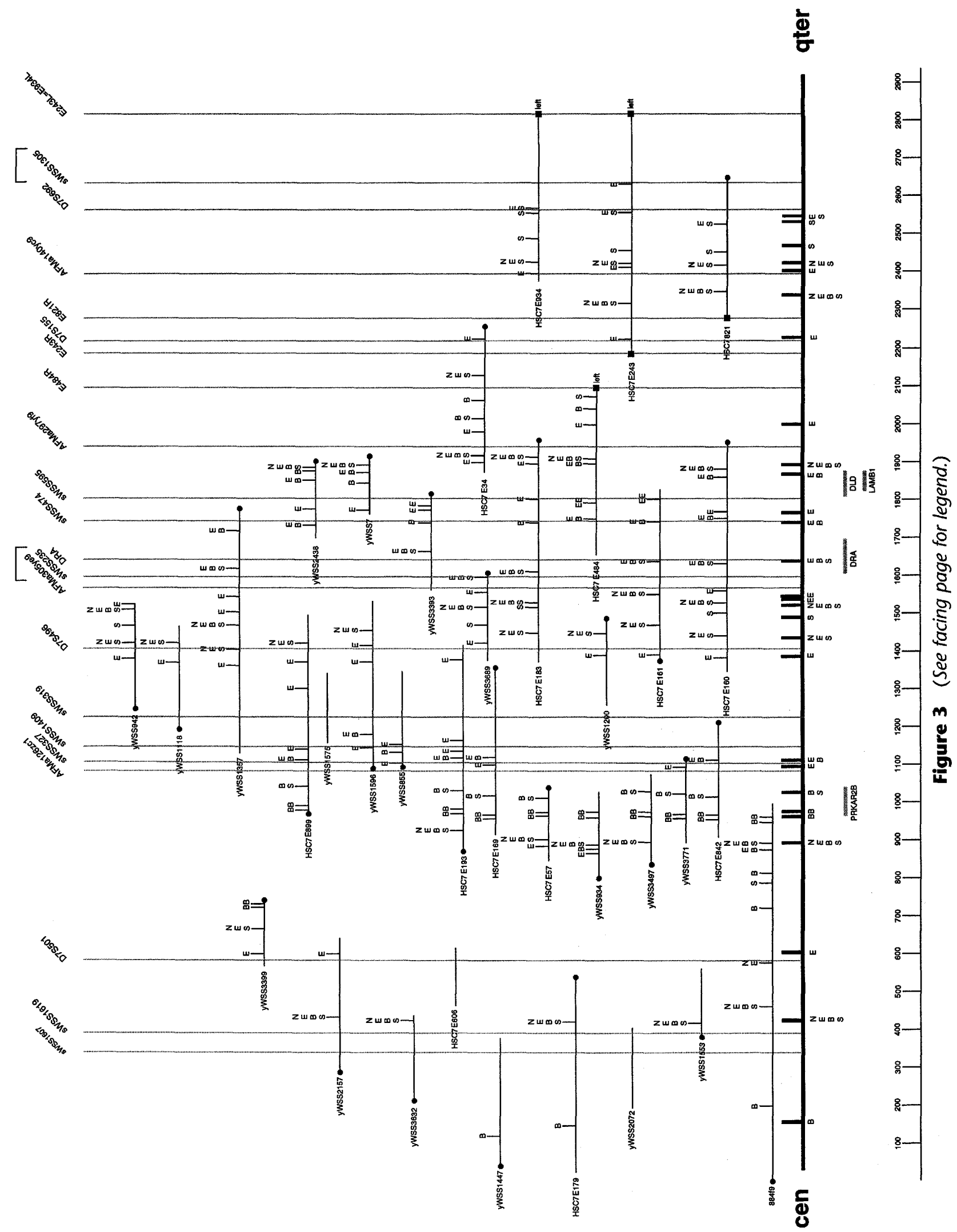


HOGLUND ET AL.

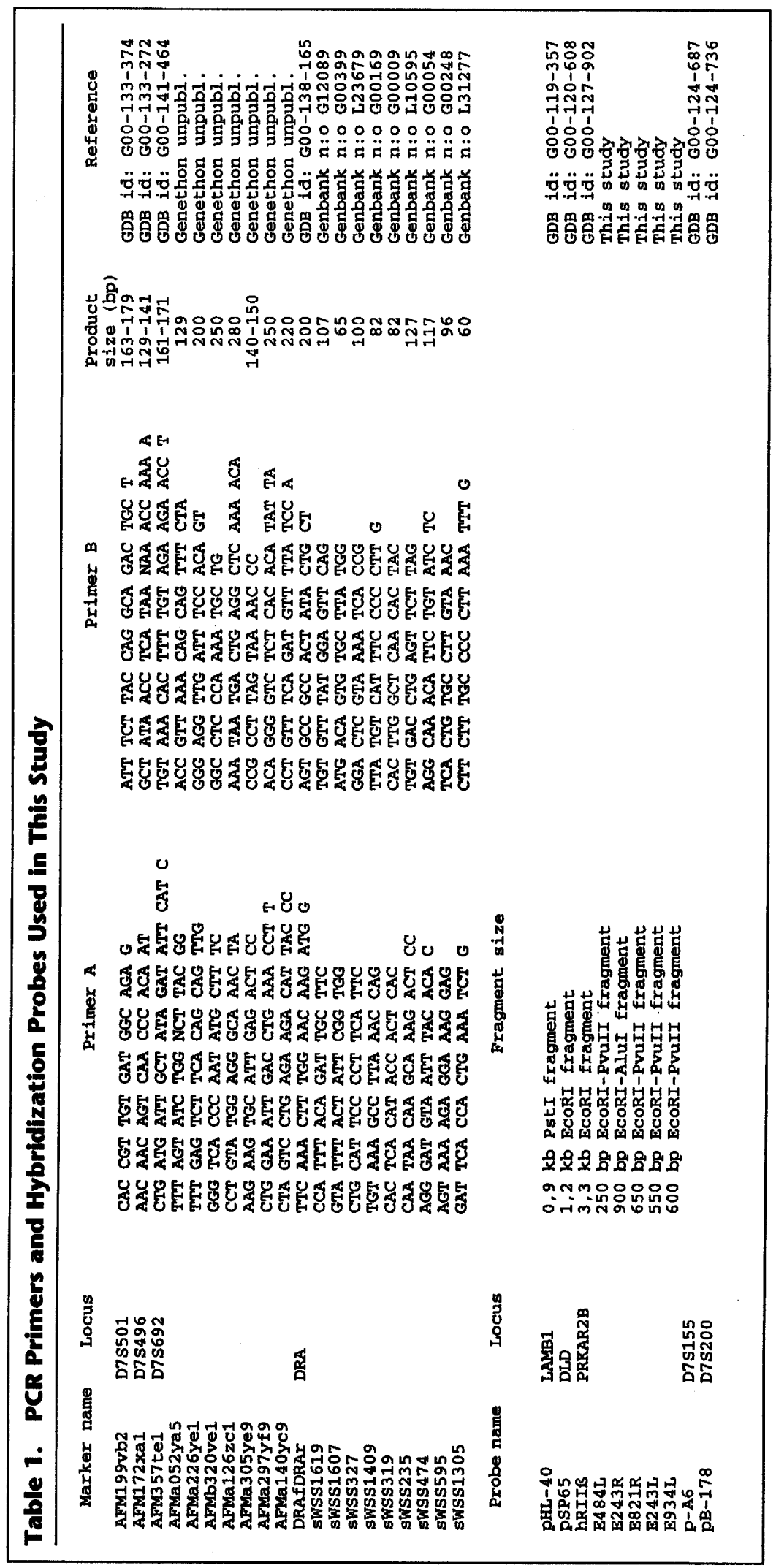


PHYSICAL MAPPING IN THE CLD GENE REGION

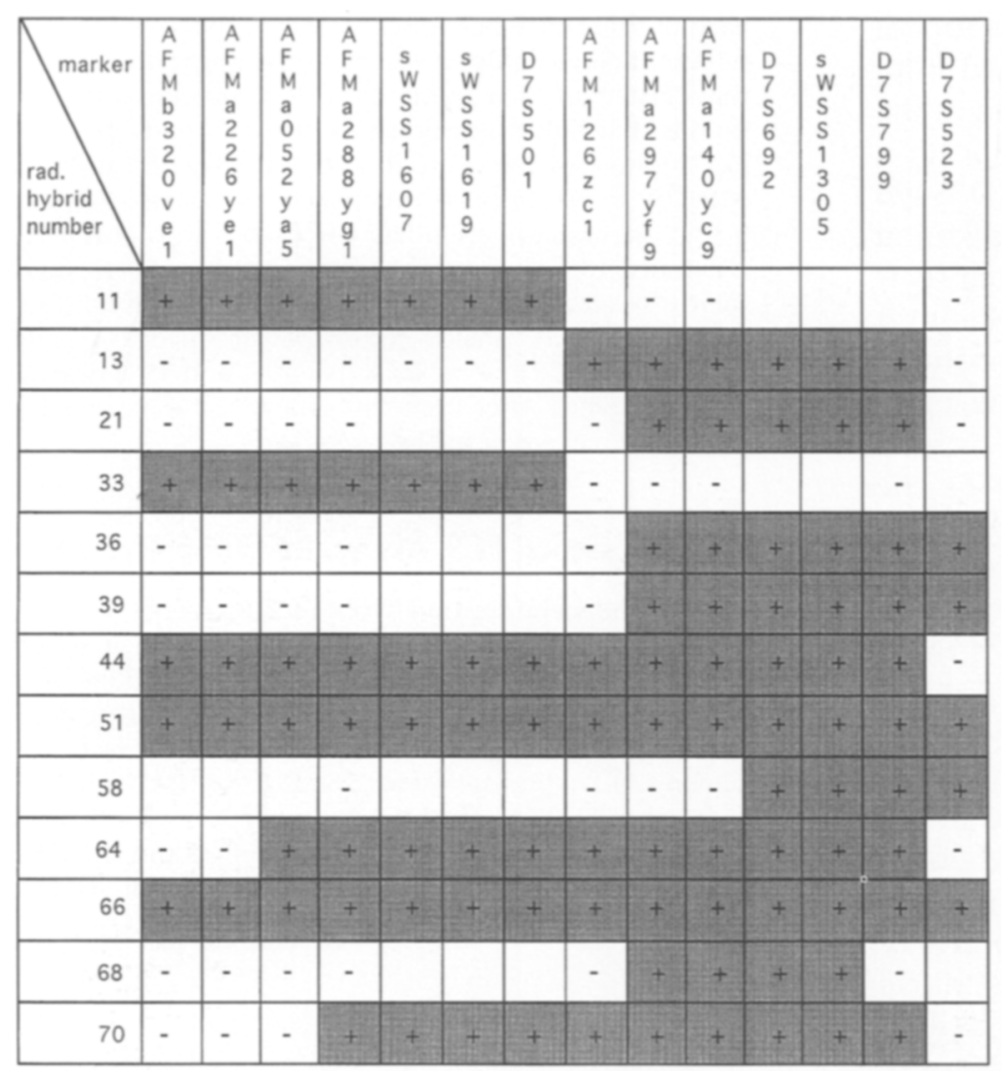

Figure 4 Radiation hybrid panel refines and extends the detailed physical map. Results are shown for clones (vertical) that allowed ordering of markers (horizontal) within and outside the YAC-based map. (+) The hybrids that are positive for a marker studied; $(-)$ the negative hybrids.

ization with a specific probe (pHL-40) in the vicinity of one such island (not shown). These results suggested indirectly a likely orientation for the gene cen- $3^{\prime}-5^{\prime}-$ qter.

\section{DISCUSSION}

This study was initiated to aid in the positional cloning of the gene causing congenital chloride diarrhea. The genetic mapping of CLD well within the reach of physical mapping techniques, $0.37 \mathrm{cM}$ from the marker D7S496 and most likely telomeric of it (Höglund et al. 1995) provided a firm basis for this study. Furthermore, no restriction maps of this region were available, and physical relationships were not known between linkage markers and known genes that might be candidates for CLD. Therefore, it was necessary first to construct a high-resolution physical map; we report here the contiguous cov- erage of $2.7 \mathrm{Mb}$ of DNA that must contain the CLD gene (Höglund et al. 1995).

The initial contigs of YACs were constructed by systematic STS content mapping by identifying clones positive for D7S496, D7S501, D7S692, and their neighboring clones. Gaps were closed by targeted end-fragment isolation. The final physical map was verified by restriction mapping and hybridization with specific probes. The restriction sites between D7S501 and AFMa126zc1 remain ambiguous because of inconsistency in two YACs. However, the distance between these markers is likely to be estimated correctly, based on the same size NotI fragment in three megaYACs. A radiation hybrid panel was used to confirm and refine the order and orientation of an additional three polymorphic markers in relation to the physical and genetic maps, thus providing an opportunity to evaluate these new markers in the haplotype analysis of CLD patients (Fig. 4). The summary restriction map (Fig. 3) was based on consistent sites in at least two overlapping YAC clones.

Four previously cloned genes and nine CpG islands were mapped within $500 \mathrm{~kb}$ of D7S496. Of these, DRA maps $250 \mathrm{~kb}$ telomeric of D7S496 and is expressed in colon but down-regulated in adenomas and adenocarcinomas of the colon (Schweinfest et al. 1993). DRA displays a strong amino acid sequence similarity to two genes encoding sulfate transporters, namely the diastrophic dysplasia sulfate transporter gene (DTDST; Hästbacka et al. 1994) and the rat sulfate anion transporter gene (sat-1; Bissig et al. 1994), and recently, its role in sulfate transport was confirmed (Silberg et al. 1995). The candidacy of DRA as CLD is based on location, expression pattern, and in part, function. It is tempting to speculate that DRA might act as an anion transporter with a significant role in chloride and bicarbonate trafficking in the gut.

A second interesting candidate gene is PRKAR2B, which maps $350 \mathrm{~kb}$ centromeric of D7S496 and encodes a regulatory subunit of cyclic adenosine $3^{\prime}, 5^{\prime}$-monophosphate (cAMP)dependent protein kinase. Protein kinases are the common denominators of the diverse effects of 


\section{HÖGLUND ET AL.}

cAMP. They are activated by a dissociation of catalytic and regulatory subunits RII $\alpha$ and RII $\beta$. Speculatively, PRKAR2B might be involved in the regulation of anion transport, but its location centromeric rather than telomeric of D7S496 makes it a less persuasive candidate. LAMB1 and DLD map $450 \mathrm{~kb}$ telomeric of D7S496, but their known functions (LAMB1 encodes the laminin $\beta 1$ chain and DLD encodes dihydrolipoamide dehydrogenase) do not immediately suggest a role in chloride diarrhea. Because CPG islands mark the $5^{\prime}$ end of many genes (Bird 1986), the identification of at least six clusters of rare-cutter restriction sites within $500 \mathrm{~kb}$ telomeric of D7S496 suggests that many genes remain unrecognized in this region. Potentially, one of them might encode a previously unrecognized product related to CLD.

Positional cloning is increasingly using knowledge of previously cloned genes that become positional candidate genes. Detailed physical maps are necessary tools for identifying such positional candidates. For positional cloning of CLD, we refined a physical map of the critical region and identified known genes as excellent candidates. The YACs in the CLD region proved to have a low rate of chimerism or deletions, and thus the clones will be suitable also for detailed analysis of gene organization. In addition, these clones will enable the isolation of new genes.

\section{METHODS}

\section{YACS}

YACs were obtained from three sources. The "yWSS" YACs were isolated from a collection of chromosome 7-enriched clones (Green et al. 1995) consisting of both humanhamster hybrid cell line-derived YACs and clones isolated from total genomic libraries constructed at Washington University (Green et al. 1994) and CEPH. The "HSC" YACs were from a chromosome 7-specific library (Scherer et al. 1992) constructed at the Hospital for Sick Children (Toronto, Canada). CEPH YACs were from the megaclone collection (Cohen et al. 1993). Contigs are being constructed in each center by systematic approaches using random or end-fragment STSs, polymorphic markers, or gene-specific probes. YAC clones were colony-purified, and DNA was prepared according to standard procedures (Brownstein et al. 1989). The sizes of YACs were determined by pulsed-field gel electrophoresis (Chu et al. 1986).

\section{Long-range Restriction Mapping}

Restriction maps of the YACs were constructed by studying series of partial digestions with the following rarecutter restriction enzymes: NotI, EagI, BssHII, and SacII.
Each of these enzymes contains at least two CG dinucleotides in their recognition sequence, making it highly likely that clusters of their recognition sites coincide with $\mathrm{CpG}$ islands that tend to associate with the $5^{\prime}$ ends of genes. Electrophoreses were run at $15^{\circ} \mathrm{C}$ for $20-30 \mathrm{hr}$ at $200 \mathrm{~V}$ with 25 - to 70 -sec pulse time using $1 \%$ agarose gels and $0.5 \times$ TBE buffer in a Bio-Rad CHEF-DR2 apparatus. DNA was transferred to nylon membranes (Hybond N+; Amersham) by alkaline blotting. Membranes were hybridized with $\left[\alpha-{ }^{32} \mathrm{P}\right] \mathrm{dCTP}$-labeled vector-specific or locus-specific probes (Table 1) in $1 \mathrm{M} \mathrm{NaCl}, 1 \%$ SDS, and 10\% dextran sulfate at $65^{\circ} \mathrm{C}$. After high-stringency washes, autoradiographs were exposed for 1-7 days.

\section{Markers, Genes, PCR Assays, Radiation Hybrids}

Primers and hybridization probes for the genes are summarized in Table 1. Insert end fragments of YACs were isolated by ligation-mediated PCR as described (Kere et al. 1992). PCR products were excised from low-melting point agarose gels (NuSieve GTG, FMC) and used directly for labeling and hybridization with Southern filters with TaqIdigested YAC DNA. The Stanford radiation hybrid panel G3 was purchased from Research Genetics, and the DNA content of each clone was assayed by PCR for selected markers specific for chromosome 7 (Table 1 ).

\section{ACKNOWLEDGMENTS}

This study was supported by the Ulla Hjelt Fund, the Duodecim Foundation, the Academy of Finland, the Sigrid Juselius Foundation, the Finnish Cancer Organizations, the National Institutes of Health, and the Canadian Genome Analysis and Technology Program. Part of the study was performed at the Folkhälsan Institute of Genetics.

The publication costs of this article were defrayed in part by payment of page charges. This article must therefore be hereby marked "advertisement" in accordance with 18 USC section 1734 solely to indicate this fact.

\section{REFERENCES}

Bird, A.P. 1986. CpG-rich islands and the function of DNA methylation. Nature 321: 209-213.

Bissig, M., B. Hagenbuch, B. Stieger, T. Koller, and P.J. Meier. 1994. Functional expression cloning of the canalicular sulfate transport system of rat hepotocytes. J. Biol. Chem. 269: 3017-3021.

Brownstein, B.H., G.A. Silverman, R.D. Little, D.T. Burke, S.J. Korsmeyer, D. Schlessinger, and M.V. Olson. 1989. Isolation of single-copy human genes from a library of yeast artificial chromosome clones. Science 244: 1348-1351.

Burke, D.T., G.F. Carle, and M.V. Olson. 1987. Cloning of large segments of exogenous DNA into yeast by means of artificial chromosome vectors. Science 236: 806-812.

Chu, G., D. Vollrath, and R.W. Davis. 1986. Separation 


\section{PHYSICAL MAPPING IN THE CLD GENE REGION}

of large DNA molecules by contour-clamped homogeneous electric fields. Science 234: 1582-1585.

Cohen, D., I. Chumakov, and J. Weissenbach. 1993. A first-generation physical map of the human genome. Nature 366: 698-701.

Cox, D.R. 1995. Mapping with radiation hybrids. Genome Digest (April), pp. 14-15.

Darrow, D.C. 1945. Congenital alkalosis with diarrhea. J. Pediatr. 26: 519-532.

Gamble, J.L., K.R. Fahey, J. Appleton, and E. McLachlan. 1945. Congenital alkalosis with diarrhea. J. Pediatr. 26: $509-518$.

Green, E.D. and M.V. Olson. 1990. Systematic screening of yeast artificial chromosome libraries by use of the polymerase chain reaction. Proc. Natl. Acad. Sci. 87: 1213-1217.

Green, E.D., J.K. Idol, R.M. Mohr-Tidwell, V.V. Braden, D.C. Peluso, R.S. Fulton, H.F. Massa, C.L. Magness, A.M. Wilson, J. Kimura, J. Weissenbach, and B.J. Trask. 1994. Integration of physical, genetic, and cytogenetic maps of human chromosome 7: Isolation and analysis of yeast artificial chromosome clones for 117 mapped genetic markers. Hum. Mol. Genet. 3: 489-501.

Green, E.D., V.V. Braden, R.S. Fulton, R. Lim, M.S. Ueltzen, D.C. Peluso, R.M. Mohr-Tidwell, J.R. Idol, L.M. Smith, I. Chumakov, D. Le Paslier, D. Cohen, T. Featherstone, and P. Green. 1995. A human chromosome 7 yeast artificial chromosome (YAC) resource: Construction, characterization, and screening. Genomics 25: 170-183.

Gyapay, G., J. Morissette, A. Vignal, C. Dib, C. Fizames, P. Millasseau, S. Marc, G. Bernardi, M. Lathrop, and J. Weissenbach. 1994. The 1993-94 Généthon human genetic linkage map. Nature Genet. 7: 246-339.

Hästbacka, J., A. de la Chapelle, I. Kaitila, P. Sistonen, A. Weaver, and E. Lander. 1992. Linkage disequilibrium mapping in isolated founder populations: Diastrophic dysplasia in Finland. Nature Genet. 2: 204-211.

Hästbacka, J., A. de la Chapelle, M.M. Mahtani, G. Clines, M.P. Reeve-Daly, M. Daly, B.A. Hamilton, K. Kusumi, B. Trivedi, A. Weaver, A. Coloma, M. Lovett, A. Buckler, I. Kaitila, and E.S. Lander. 1994. The diastrophic dysplasia gene encodes a novel sulfate transporter: Positional cloning by fine-structure linkage disequilibrium mapping. Cell 78: 1073-1087.

Höglund, P., P. Sistonen, R. Norio, A. Dimberg, K.-H. Gustavson, A. de la Chapelle, and J. Kere. 1995. Fine mapping of the congenital chloride diarrhea gene by linkage disequilibrium. Am. J. Hum. Genet. 57: 95-102.

Holmberg, C., J. Perheentupa, and K. Launiala. 1975. Colonic electrolyte transportion in health and in congenital chloride diarrhea. J. Clin. Invest. 56: 302-310.
Holmberg, C., J. Perheentupa, K. Launiala, and N. Hallman. 1977. Congenital chloride diarrhea. Clinical analysis of 21 Finnish patients. Arch. Dis. Child. 52: $255-267$.

Kere, J., R. Nagaraja, S. Mumm, A. Ciccodicola, M. $D^{\prime}$ Urso, and D. Schlessinger. 1992. Mapping human chromosomes by walking with sequence-tagged sites from end fragments of yeast artificial chromosome inserts. Genomics 14: 241-248.

Kere, J., P. Sistonen, C. Holmberg, and A. de la Chapelle. 1993. The gene for congenital chloride diarrhea maps close to but is distinct from the gene for cystic fibrosis transmembrane conductance regulator. Proc. Natl. Acad. Sci. 90: 10686-10689.

McKusick, V.A. 1994. Mendelian inheritance in man, 11th ed. Johns Hopkins University Press, Baltimore, MD.

Murray, J.C., K.H. Buetow, J.L. Weber, S. Ludwigsen, T. Scherpbier-Heddema, F. Manion, J. Quillen, V.C. Sheffield, S. Sunden, G.M. Duyk et al. 1994. A comprehensive human linkage map with centrimorgan density: Cooperative Human Linkage Center (CHLC). Science 265: 2049-2054.

Norio, R., J. Perheentupa, K. Launiala, and N. Hallman. 1971. Congenital chloride diarrhea, an autosomal recessive disease. Clin. Genet. 2: 182-192.

Pikkarainen, T., R. Eddy, Y. Fukushima, M. Byers, T. Shows, T. Pihlajaniemi, M. Saraste, and K. Tryggvason. 1987. Human laminin B1 chain, a multidomain protein with gene (LAMB1) locus in the q22 region of chromosome 7. J. Biol. Chem. 262: 10454-10462.

Rommens, J.M., S. Zengerling, J. Burns, G. Melmer, B.S. Kerem, N. Plavsic, M. Zsiga, D. Kennedy, D. Markiewicz, R. Rozmahel et al. 1988. Identification and regional localization of DNA markers on chromosome 7 for the cloning of the cystic fibrosis gene. Am. J. Hum. Genet. 43: $645-663$.

Scherer, S.W., G. Otulakowski, B.H. Robinson, and L.-C. Tsui. 1991. Localization of the human dihydrolipoamide dehydrogenase gene (DLD) to $7 \mathrm{q} 31-\mathrm{q} 32$. Cytogenet. Cell Genet. 56: 176-177.

Scherer, S.W., B.J.F. Tompkins, and L.-C. Tsui. 1992. A human chromosome 7-specific genomic DNA library in yeast artificial chromosomes. Mamm. Genome 3: $179-181$.

Schweinfest, C.W., K.W. Henderson, S. Suster, N. Kondoh, and T.S. Papas. 1993. Identification of a colon mucosa gene that is down-regulated in colon adenomas and adenocarcinomas. Proc. Natl. Acad. Sci.

90: $4166-4170$.

Silberg, D.G., W. Wang, R.H. Moseley, and P.G. Traber. 1995. The down regulated in adenoma (dra) gene encodes an intestine-specific membrane sulfate transport protein. J. Biol. Chem. 270: 11897-11902. 


\section{HOGLUND ET AL.}

Solberg, R., P. Sistonen, A.-L. Träskelin, D. Bérubé, J. Simard, P. Krajci, T. Jahnsen, and A. de la Chapelle. 1992. Mapping of the regulatory subunits RI $\beta$ and RII $\beta$ of cAMP-dependent protein kinase genes on human chromosome 7. Genomics 14: 63-69.

Turnberg, L.A. 1971. Abnormalities in intestinal electrolyte transport in congenital chloridorrhoea. Gut 12: $544-551$.

Vuolteenaho, R., L.T. Chow, and K. Tryggvason. 1990. Structure of the human laminin B1 chain gene. J. Biol. Chem. 256: 15611-15616.

Weissenbach, J., G. Gyapay, C. Dib, A. Vignal, J.

Morissette, P. Millasseau, G. Vaysseix, and M. Lathrop. 1992. A second-generation linkage map of the human genome. Nature 359: 794-801.

Received November 28, 1995; accepted in revised form February 15, 1996. 


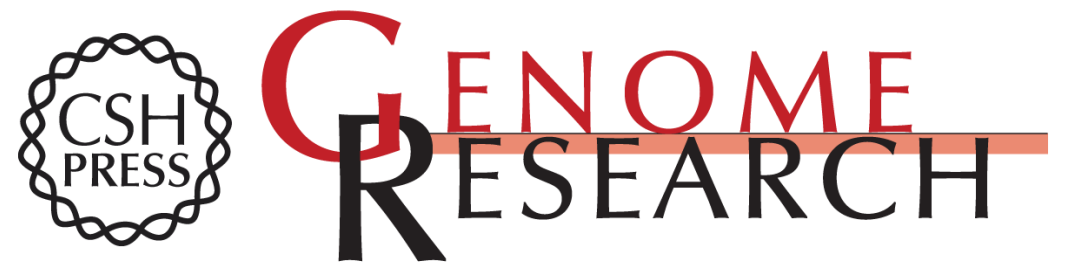

\section{Positional candidate genes for congenital chloride diarrhea suggested by high-resolution physical mapping in chromosome region $7 q 31$.}

P Höglund, S Haila, S W Scherer, et al.

Genome Res. 1996 6: 202-210

Access the most recent version at doi:10.1101/gr.6.3.202

References This article cites 31 articles, 12 of which can be accessed free at:

http://genome.cshlp.org/content/6/3/202.full.html\#ref-list-1

License

Email Alerting Receive free email alerts when new articles cite this article - sign up in the box at the Service top right corner of the article or click here.

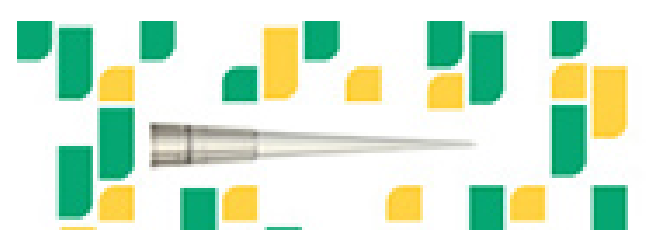

Focused on your science.

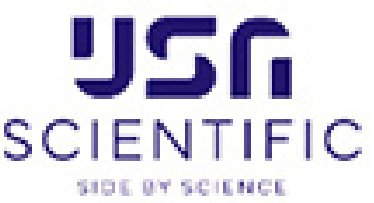

To subscribe to Genome Research go to:

https://genome.cshlp.org/subscriptions 